\title{
RETHINKING EDUCATION: A CASE FOR TARBIYAH IN CONTEMPORARY BRITAIN
}

\author{
Shahin Rahman \\ Education Studies, University of Warwick, United Kingdom \\ Shahin-Ur.Rahman@warwick.ac.uk
}

Accepted: 04-01-2021

\begin{abstract}
This paper explores solutions to the limitations of the purpose of education as currently understood and advocated in postmodern Britain. By adopting an interdisciplinary approach, it takes a closer look at the objectives of education as per another major civilisation with a rich educational heritage-that is, the Islamic tradition-and compares the two distinct philosophies. The research finds that the contemporary British philosophy of education has several drawbacks due to focusing only on building the economy and shaping a political worldview. As such, this paper discusses how Britain might mitigate its current weaknesses by suggesting to integrate the Islamic model of education (tarbiyah) in order to foster personal development, civic engagement and objectivity in research, learning and producing new knowledge-without the need compromise its strong economy.
\end{abstract}

Keywords: Philosophy of Education; Islamic Education; Education in Britain; Tarbiyah.

\section{INTRODUCTION}

This paper aims to situate the place education holds in society by analysing two contrasting worldviews surrounding the philosophy of education-in particular, Islamic tradition (both classical and modern) and contemporary British thought. However, unlike previous scholarship, ${ }^{1}$ this paper will not perpetuate a false dichotomy that the Islamic and British models of education are mutually exclusive and irreconcilable. Rather, this paper aims to synthesise the educational philosophies of two great worlds-that is, the Islamic civilisation and the modern west-thus proposing a nuanced, holistic approach to education that achieves the primary objectives of both worldviews. This is a significant issue both from the perspective of contributing nuance to the current literature on the philosophy of education, as well as addressing the myriad of hitherto unsolved political and psychological concerns on the ground: to what extent, for example, is education responsible for economic growth? What is the role of education in building self-development and empathy for others among learners? A closer look at these questions can aid in refining the educational model to actually meet the goals of education, which is what this paper will explore in detail. The central question this

1 See Bradley J. Cook, "Islamic Versus Western Conceptions of Education: Reflections on Egypt," International Review of Education 45, no. 3 (1999): 339-358. https://doi.org/10.1023/A:1003808525407 
paper aims to answer, then, is this: what should be the aims of education, and what role should education have in society?

As a British Muslim with a background not only in British schooling but also in traditional Islamic seminary training, the writer takes a personal interest in the theoretical nature of education and its implementation in the physical world, as well as the potential consequences for society. As such, this paper will discuss, analyse and compare contemporary British philosophies of education with the major educational aims outlined in Islamic texts and Muslim scholarship, then propose new directions in achieving the goals of both worldviews within the existing framework.

\section{Islamic philosophies of education}

This section focuses on the educational philosophy within the Islamic educational paradigm. Islam's attitude towards learning is distinct in multiple ways. For example, a prophetic tradition (hadith) reports the Prophet Muhammad saying that learning is not only a right but a legal duty and moral obligation. ${ }^{2}$ The Qur' an, Islam's primary authoritative text and scripture, corroborates this foundational premise and sentiment, as not only did Prophet Muhammad 紧 teach this to others, but rather, the Qur' an itself orders him to supplicate, 'My Lord, increase me in knowledge'.

A second factor towards understanding Muslims' conception of learning is the fact that the lingua franca of Islamic academic discourse is not English but Arabic. ${ }^{4}$ Consequently, the Islamic viewpoint with regard to education is shaped not only by direct teachings from the scriptures of Islam, but also by the nuances of the Arabic language, as language forms an 'integral part' of a people's philosophy and worldview. ${ }^{5}$ As such, this section discusses the foundational aim of education in Islamic thought and explores its manifestation as various consequential educational aims.

Sahin asserts that the Arabic word that comprehensively denotes in full the concept of education is tarbiyah, which comes from the triliteral root $\mathrm{r}-\mathrm{b}-\mathrm{w}$, meaning 'to increase, nurture and facilitate'. In other words, the Arabic word for education is deeply rooted in the concept of growth and self-development. Stemming from the idea of personal, social, spiritual and academic growth are the many sub-aims of the Islamic approach to education. Broadly, these include (and are not limited to) putting knowledge into practice, educating others to rectify the community and, most importantly, to find God through His signs. ${ }^{6}$ Although there might be more educational aims within the Islamic educational paradigm, this paper will focus only on the above inferences, which are among the most prominent in the literature. ${ }^{7}$

The educational aim of putting knowledge to correct practice comes from the primary sources of Islam. For instance, the Qur' an rebukes the learned who preach to others what

\footnotetext{
2 Ibn Mājah: 224. Shu 'ayb al-Arna' ùt graded it hasan due to its multiple chains.

${ }^{3}$ All translations of Arabic texts in this paper, unless otherwise stated, are my own. Verses from the Qur' an are cited with their chapter and verse numbers.

${ }^{4}$ Abū Isḥāq al-Shāṭibī, Al-I tișām (Riyadh: Dār Ibn al-Qayyim, 2010).

5 See Jeanette King, "The Worldview of Second Language Speakers of Māori." In Indigenous Language Revitalization: Encouragement, Guidance \& Lessons Learned, ed. Jon Reyhner and Louise Lockard (Arizona: Northern Arizona University, 2009), 102.

${ }^{6}$ Abū Ḥāmid al-Ghazālī, Iḥyà' 'Ulūm al-Dìn (Jeddah: Dār al-Minhāj, 2011).

${ }^{7}$ al-Ghazālī, Ihyyà .
} 
they fail to practise themselves. In another source, the Prophet Muhammad also gave severe warnings for the 'one who seeks knowledge to compete with the learned, argue with [the unlearned] or turn the people's attention towards oneself. ${ }^{8}$ Another account records the Prophet Muhammad emphasising good character, such that through it a person can reach the ranks of those who fast all day and stand in prayer all night. ${ }^{9}$ Further still, al-Naysābūrī reports that the Prophet Muhammad the feferred to those who fail to adorn themselves with proper mannerisms by violating the rights of others as 'bankrupt'. ${ }^{10}$ All of these accounts demonstrate that putting knowledge to practice and adopting befitting character are foundational aims of education in Islam.

The educational aim of building a more learned community is likewise an explicit objective of learning as found in the Qur'an, where learners and scholars are expected to 'warn their people when they return to them so that they may be vigilant'. The $12^{\text {th }}$ Century Muslim thinker al-Ghazāli considers this verse to be a virtue not only of learning but also of teaching. Thus, teaching others - and, by extension, nurturing the community to grow - is a desired aim of education in Islam. The father of sociology Ibn Khaldūn further corroborates this sentiment by highlighting the interlinked nature of knowledge and civilisation. One way in which Islam creates a knowledge-centric society is by raising the prestige of knowledge and its bearers. An example is the Qur' an declaring that 'Allah raises in ranks those who [...] are given knowledge'. Another example is the account that the Prophet Muhammad likened the virtue of scholars above the public to the brightness of the moon over the stars on a moonlit night. ${ }^{11}$ This incentivises the desire for education in the community and thus creates more nurturers who play a significant role in the betterment of the society.

The most important and primary aim of education in Islam is to find God through recognising His signs. This is evident from the fact that the oft-quoted verse of the Qur' an in praise of the educacted, 'The only ones who fear Allah from among His servants are the learned' (35:28), is preceded by a call to reflectively engage with the natural sciences to appreciate the meticulous power of God. Thus, it is clear from the Qur' anic rhetoric that the objective of engaging with the knowledge of the world is to intellectually and experientially recognise the authority of God. Recent studies in Islamic Education show that some classical Muslim exegetes understood Ezekiel's vision in the Old Testament in a pedagogical light of how the vision led Ezekiel to 'understand experientially [God's] power of resurrection. ${ }^{12}$ Also, considering the Qur'an asserts that mankind's sole purpose of existence is 'to worship [Allah]', it is inevitable that Islam's primary aim of education will be a stepping stone to achieving this goal. A recent study found that al-Ghazāli draws the same conclusion. ${ }^{13}$ This

\footnotetext{
8 Tirmidhī: 2845. In most editions, this will be cited as 2654. Shu'ayb al-Arna'ūt graded it hasan due to supporting narrations.

${ }^{9}$ Abū Dāwūd: 4798. Shu 'ayb al-Arna' ùt graded it șaḥịh due to supporting narrations.

${ }^{10}$ Muslim: 2581.

${ }^{11}$ Abū Dāwūd: 3641. Shu 'ayb al-Arna' ūṭ graded it hasan due to supporting narrations.

12 Abdullah Sahin, New Directions in Islamic Education: Pedagogy \& Identity Formation (Markfield: Kube Publishing, 2013), 188.

13 Sajid Ullah Sheikh and Muhammad Abid Ali, "Al-Ghazali's Aims and Objectives of Islamic Education," Journal of Education and Educational Development 6, no. 11 (2019): 111-125. https://eric.ed.gov/?id=EJ1216762
} 
has political and economical implications, as will be addressed later on in this paper, amid the discussion on the strengths and weaknesses of this model.

In short, according to Islam's educational paradigm, education holds a pivotal place on both a personal and societal level. It maintains that the aim of seeking an education ought to be for the sake of reaching God through truth and knowledge, and implementing that knowledge into practice not only in private affairs but also in communal matters that affect the public, enabling learners and their communities to grow in every way possible, thereby becoming a paragon of virtue.

\section{British philosophies of education}

This section looks at some of the British philosophies concerning education. According to Sahin, the Latin word educare, the etymological origin of the English word education, along with the Greek 'pedagogy', both share meanings that closely resemble that of the Arabic word tarbiyah. In essence, where tarbiyah means 'to increase, nurture and facilitate', educare means 'springing up into existence, nurturing and leading', while pedagogy in the Greek originally meant to 'lead the child'. Noteworthy is the point that while the Islamic education paradigm centres around the concept of growth and nurture, contemporary British philosophies of education appear to have deviated from the linguistic essence from which education as an academic discipline emerged. This is evident from the fact that the British philosopher of education Pring lists multiple aims of education in the academic literature. These include 'being and developing as a person', yet this is not yet reflected in mainstream theory and practice, which are discussed below.

As such, the most prominent aims of education according to mainstream philosophers of education are two: firstly, to prepare learners for the workforce, ${ }^{14}$ and secondly, to influence their political worldview, albeit implicitly. ${ }^{15}$ Both of these will be the focus of this section.

Insofar as education for the workforce is concerned, it has been a recurring theme across the literature throughout the recent decades. In his 1986 work, Barnes (cited in Moore) draws a relationship between curriculum content and pedagogic styles with what Moore refers to as an 'unspoken educational purpose' - that is, 'to 'control', 'select' and 'contain' the working population'. Winch justifies this aim and argues that preparation for the workforce is a reasonable objective of education, partly because employment has 'intrinsic worth', and partly because of the need to maintain a 'healthy economy'. In more recent times, contemporary philosopher of education Pring tacitly approves this sentiment, despite challenging the consistency of its application in modern Britain. Not only does he legitimise it as an intrinsic aim of education; he goes on to admit that educational arrangements are 'increasingly organised to serve economic [...] interests'.

Moving forward to political influence, Moore posits that not only are there 'official' purposes of education, but that educational policy also includes what he refers to as an 'unofficial official' agenda. Drawing on recent scholarship and an analysis of secondary documents, he acknowledges the 'hidden' or 'unofficial official' agenda seeks to 'perpetuate

14 Christopher Winch, "The Economic Aims of Education," Journal of Philosophy of Education 36, no. 1 (2002): 101-117. https://doi.org/10.1111/1467-9752.00262

15 Alex Moore, Teaching and Learning: Pedagogy, Curriculum and Culture (Abingdon: Routledge, 2012). 
economic and social division within society' . In more recent scholarship, Pring goes a step further and reveals that political leaders ask 'us' (philosophers of education) to run schools in accordance to research results that are most conducive to achieving their political interests, thus leading to a 'political control' over the teachers. The implications of this practice will be discussed in the next section.

In summary, contemporary British thought views education as a product that aims to prepare learners for the workforce to help maintain a strong economy. It views education's place in society as a political tool that can be manipulated for political interests.

\section{Discussions and critiques of the current British discourse}

This section of the paper will discuss and critique the current and dominant British model of the philosophy of education, as outlined above, from two angles: philosophical and scientific. As for the philosophical aspect, only one criticism will be made, as this tackles the very foundation of the narrative; and as for the implications of its practice as applied in the real world, both positive and negative implications will be discussed in this section of the paper.

Philosophically speaking, unlike the Islamic philosophy of education, which has a coherent narrative beginning with a God-centric worldview that leads to education being a part of holistic way of life in a logically progressive way, British attitudes to the philosophy of education appear largely arbitrary. In his article on the economic aims of education, for example, Winch justifies preparation for the workforce as being a 'worthwhile aim' by failing to 'see why not'. This makes an in-depth analysis of the proposal all the more difficult, as there are no ontological criteria that transcend human subjectivity by which to judge the coherence of his philosophy. This is not uncommon in social sciences: for example, sociologists of childhood posit that the reason children play is because they are free from adult duties and 'have no responsibilities, ${ }^{16}$ yet they fail to substantiate their claim with any form of objective criteria. Therefore, from a purely philosophical perspective, there is no objective rationale in the literature that can coherently justify the reasoning behind much of the proposed educational aims - at the very least, preparation of the workforce - being inherent goals of the discipline that is education.

As for the implications of this model when applied to the real world, there have been both positive and negative impacts on the ground. In terms of its strengths, it is no secret that the British economy has been among the most competitive in the world. ${ }^{17}$ On the other hand, the political influence in education has led to those with greater power dynamics exploiting their subordinates, not only financially but also pedagogically, such that thinkers from disadvantaged backgrounds wrote academic books on the topic. ${ }^{18}$ Economically speaking, it is worth highlighting the irony of reducing education to nothing more than an economical tool: more and more graduates of higher education are left either without jobs or are employed in

\footnotetext{
${ }^{16}$ Michael Wyness, Childhood and Society (London: Palgrave Macmillan, 2012), 11.

17 György Borus, "A New Account of Britain's Economic Development," Hungarian Journal of English and American Studies 23, no. 1 (2017): 229-241.

18 See Paolo Friere, Pedagogy of the Oppressed (New York: The Continuum International Publishing Group Inc, 2005).
} 
jobs that do not maximise their potential. Battu \& Sloane describe workers whose jobs do not require their current qualifications as being 'over-educated'.

Additionally, education has largely become a passive reception rather than an active endeavour, which Friere considers nothing short of a 'characteristic of the ideology of oppression'. Not only that; reducing education to vocational training has led to the fall of teachers' prestige, to the point that Pring felt compelled to make a plea to his readers to 'respect teachers' once again. None of the current academic literature that put forward preparation of the workforce or achieving political goals as the fundamental aims of education offer a solution to this problem. ${ }^{19}$ A genuine solution to this problem is attainable, as will be posited towards the end of this paper. Notwithstanding, the constant change of governmental policy on education means the curriculum changes too frequently, resulting in a lack of fully attaining the goal of any one plan at a given time. This is a phenomenon acknowledged by academics on both sides of the political spectrum. ${ }^{20}$ This too can be solved, as will be discussed in the section after next in this paper.

Accordingly, the mainstream philosophies of education have more weaknesses than strengths; therefore, it follows that the aims of education should be not the existing mainstream ideas but an alternative model derived from elsewhere. It also follows that the role of education in society should be something more than an extended job training.

\section{Discussions and critiques of Islamic aims of education}

This section will discuss the strengths and weaknesses of educational aims as per the Islamic paradigm.

Where Pring pleas to contemplate what is means to be educated in the today's era, he also pleas that the answer should include 'a sense of moral purpose and civic engagement,' as it is these that 'make us distinctly human'. Islam's ageless educational paradigm had not only addressed this but also actively made it a living reality over 14 centuries ago. The God-centric nature of Islam's philosophy of education, which, according to al-Ghazâlī, is the ultimate aim of education, ${ }^{21}$ ensures every learner has a sense of moral purpose and is thus academically objective in his or her learning adventure. Contemporary economist El Diwany confirms this sentiment and asserts that a 'proper education in Islamic values and etiquettes [sic]' will maintain standards of human behaviour through 'internal moral regulation'.

In terms of civic engagement, Islam considers it a foundational aim of education, as mentioned earlier in this paper when outlining the Islamic philosophy of education. It is important to note at this junction that Islam is an interdisciplinary philosophy that is broad in its content, of which education is but one discipline. ${ }^{22}$ Therefore, to fully appreciate Islam's educational paradigm, it is imperative to also consider its political worldview, economic models and community values. Thus, where Muslim educationists are silent on matters that are otherwise widely discussed in mainstream education theory, it is likely that the matters in question pertain not to Islamic education per se but to Islam's welfare system or lifestyle

\footnotetext{
${ }^{19}$ See Moore, Teaching and Learning.

${ }^{20}$ See Tony Burgess, "Education in Britain, 1944 to the present: a response to Ken Jones's book of that title," Changing English 11, no. 1 (2004): 31-38. https://doi.org/10.1080/1358684042000179417

${ }^{21}$ Sheikh and Ali, Al-Ghazali's Aims and Objectives.

22 See al-Ghazālī, Ihyā'.
} 
choices. With respect to education for civic engagement, not only is it a direct teaching in the Qur'an itself, but it was a core aim of education in the Islamic tradition, as $11^{\text {th }}$ Century scholar Ibn Sīnā (Avicenna) had also advocated. ${ }^{23}$

Furthermore, the morality-centric nature of education in the Islamic paradigm will mitigate against the temptations to tamper with the curriculum for a sociopolitical or any other sinister agenda. ${ }^{24}$ This is more conducive to creating a more objective exposure to knowledge, paving the way for discussions to be had on a mature and academic level, and also accommodating for a spectrum of diverse opinions. According to contemporary Saudi-based thinker and academic al- 'Awnī, the primary sources of Islam acknowledge that human beings will not cease to differ, and thus permit a spectrum of views to coexist simultaneously, even under one governing entity. The American academic Brown presents historical examples of pluralistic societies in Egypt and Bosnia, where Shariah courts not only appreciated but 'took advantage' of legal plurality that Islam accommodates. Applying this concept to accommodate for a plethora of educational models within one country can likewise mitigate the chances of political influence within the education sector. This will be discussed in more detail in the next section.

A criticism that can be levelled against the Islamic model of education is that it does not seek to contribute to the economy in any way. A response to this has already been given above, that Islam's teachings are interdisciplinary and thus expand beyond education theory. In other words, not only does Islam offer nuanced guidelines for the philosophy of education; it also provides insightful political and economical models, among others. The depth of its economic model can be gauged from the works of the Egyptian scholar and academic alQaraḍāwī, who published his PhD research on the laws and philosophy of Islam's profound welfare system, the institution of Zakat, a significant pillar of the five pillars of Islam that advocates a secure economic model that guarantees a reasonable distribution of wealth across the rich and poor. As for building the economy, $10^{\text {th }}$ Century Islamic scholar al-Khallāl compiled 128 statements from the Prophet Muhammad (and early Muslims from the formative years of Islamic scholarship) that advocate earning a living and condemn those who adopt a complacent attitude towards a life of work.

Another criticism that may cross the reader's mind is that Islam's God-centric philosophy of education appears to have no room for atheists or believers who wish to opt for a secular approach to their education. However, as outlined earlier, the first two aims of education in the Islamic paradigm are personal development and civic engagement, neither of which are dichotomous with existing secular philosophies. For instance, contemporary British philosopher of education Pring considers 'being and developing as a person' part of what it means to be an 'educated person'. He also emphasises the need for a 'sense of moral purpose'. Both of these fall under the first aim of education as per the Islamic narrative, outlined earlier in the paper. As for contributing to society and making the world a better place, Pring likewise makes a plea for 'civic engagement' to be included in the discussions surrounding what it means to be an 'educated person'. This is the second aim of education in

${ }^{23}$ Sebastian Günther, "Be Masters in That You Teach and Continue to Learn: Medieval Muslim Thinkers on Educational Theory," Comparative Education Review 50 no. 3 (2006): 367-388. https://doi.org/10.1086/503881

24 Tirmidhī: 2845 (or 2654). 
the Islamic paradigm. As for the third, to find God through truth and knowledge, this too is not contradictory with learners of no faith, as 'finding God' can be seen as a pedagogical framework that ensures objectivity in learning: thus, a learner, irrespective of their theological views, will seek coherence in any given subject rather than suffice with memorising trivia such as miscellaneous dates and facts, for instance. Approaching knowledge objectively and with a sense of moral purpose will inevitably lead one to recognising the oneness of God. ${ }^{25}$ This also demonstrates that the pedagogical framework (of finding God through exploring His world) interlinks with the previous aims of self-development and civic engagement. That said, however, Islamic education also has room for accommodating philosophies of academics with differing views. More on this will come in the next section.

Two things become clear from the above: that the aims of education as per the Islamic paradigm are more coherent and robust than that of the dominant practice today, and that not all British philosophies of education are dichotomous with Islamic philosophies of education. This raises a novel question: can there be a way forward by synthesising between the Islamic and contemporary British philosophies of education to create a model that is suitable for implementation in modern Britain? This is explored and discussed in the next section.

\section{New directions for education theory in the modern world}

To offer new ways forward, a closer look is required at harmonising between abstract theory and its implementation into the real world. In his famous work on the role of the 'ulama's (Muslim scholars of the various Islamic disciplines) in the modern world, Zaman demonstrates how Muslim scholars have historically engaged with and met the challenging needs of the societies in which they lived. Masud expands on this not only by going further into history but also by showing examples of $20^{\text {th }}$ Century 'ulama' embracing this role of theirs, indicating that the comprehensiveness of Islam need not contradict its dynamic nature and ability to cater for novel situations and new contexts. It is in this light, therefore, that I contribute the following proposal: that is, implementing Islamic ideals to the modern world while integrating the strengths of the mainstream British narrative will produce a robust educational model that is most conducive to the inherent aims of education, without putting the economy into jeopardy.

Firstly, in order to see meaningful change in practice, a paradigm shift is required at the higher level of the philosophy of education. In his book on Islamic Banking and Finance, El Diwany emphasises the need for a proper education on morals and values rather than materialism. This does not need to be unique to Islamic education; rather, there is appetite from mainstream philosophers of education to synthesise the two traditions. For example, Pring recognises the same need in British education. The important question is this: why should education have a moral direction to it? Equally important, why should those morals and values be taken from Islam? The answer to both questions is one and the same. In the words of Ramadan, the Swiss academic and Professor of Islamic Studies at Oxford University:

25 Mark D. Linville, “The Moral Argument." In The Blackwell Companion to Natural Theology, ed. William Lane Craig and J P Moreland (West Sussex: Blackwell Publishing Ltd, 2012), 391-448. 
The Prophet's life [...] avoids no question and teaches us-in the course of events, trials, hardships, and our quest-that the true answers to existential questions are more often those given by the heart than by the intelligence. Deeply, simply: he who cannot love cannot understand.

One significant implication of adopting the above as a foundational aim of education will be the rise of prestige among teachers and educators. The need to 'respect teachers' is echoed in academic literature. As mentioned towards the beginning of this paper, the Qur' an itself plays a role in raising the prestige of knowledge, learners and educators, as does the Prophet of Islam (This is not to say the Qur' an advocates a teacher-led pedagogy; rather, as part of his $\mathrm{PhD}$ research, Sahin dedicates a full chapter in his book on the Qur'anic pedagogy being critical, reflective and learner-led.)

Secondly, despite the need to resist materialism by prioritising moral and ethical values, that is not to say there is no room for the mainstream British sentiment of maintaining a strong economy through vocational training. Maintaining a healthy economy and resisting materialism are not mutually exclusive; they can coexist simultaneously. The Islamic model opposes not building an economy but the ideology of materialism. In an attempt to synthesise the two, I propose a new classification: rather than perpetuating the false dichotomy of academic studies and vocational training, it will be more productive to create a classification of education and professional development. Not only will this avoid blurring the lines between formal studies and job-training or the acquisition of skillsets; it also removes the stigma of vocational training by simultaneously raising its prestige by giving it a more befitting and honourable title: professionalism. More importantly, it maintains clarity of what education is and is not, and what place is has and does not have in society. The advantage of it will be the maintenance of a strong economy without political interference in the realm of education. By adopting this model, education remains moral and ethical, and the economy need not suffer. In other words, it will mitigate against the fear of materialism creeping into education while simultaneously giving room for the society to prosper economically, in not a conflicting but a complementary system where different disciplines work together for the betterment of society. This also meets the second aim of Islamic education - that is, to help the society grow through civic engagement.

Thirdly, I propose adopting not a monolithic but a pluralistic model to embrace the diverse views of scholars and academics. Not only does the Qur'an affirm the nature of humankind to hold differing views; scholars past and present have differed and continue to differ in their views on every discipline. ${ }^{26}$ After all, a number of scholars and academics will inevitably disagree with the central thesis of this paper. This is not necessarily a bad thing. Rather, it not only allows knowledge to continue to grow but also compels human beings to build their own character and demonstrate what is known in the Islamic tradition as adab alkbilaj - that is, the ethics of disagreement. ${ }^{27}$ While a pluralistic model, where a range of conflicting policies is enacted simultaneously in different schools and universities, might be

${ }^{26}$ Ḥātim al- 'Awnī, Ikehtilāf al-Muftìn wa '-Mawqif al-Mațlūb tijāhahū min 'Umüm al-Muslimìn: Mu'așșalan min Adillat al-Wahyayn (Riyadh: Dār al-Ṣamīìn, 2008).

${ }^{27}$ See Shāh Waliyyullāh al-Dihlawī, 'Iqd al-Jìd fì Ahkeàm al-Ijtihād wa '-Taqlīd (Kuwait: Dār al-Ḍiyā', 2014). See also, al- 'Awnī, Ikhtilāf al-Muftin. 
new to mainstream education theory, it has been successfully practised in Muslim scholarship throughout the world for over a millennium. ${ }^{28}$ Therefore, in order to avoid the harms of a constant change of education policies every time a new political party is elected for government, it is only reasonable to adopt a pluralistic model of education that is found across the Muslim world.

There are numerous advantages of adopting a pluralistic model of education. Firstly, it welcomes healthy discussion and debate, and encourages social experiments. Secondly, it enables people of diverse views to learn from one another. Thirdly, it accommodates space for thinkers to change their minds and adopt alternative models without causing nationwide disorder. Fourthly, it equips the community with ethics of disagreement, which, when applied correctly, maintains social harmony and unites the people through their diversity. Finally, it opens its doors to people of all faith and non-faith, giving equal opportunities to all to prosper as one family of humankind.

In sum, an ideal and practical way forward for education in Britain and around the world would be to integrate the Islamic model of education within the mainstream discourse and implement it in practice.

\section{CONCLUSIONS}

The start of this paper outlines the aims of education as per the Islamic educational paradigm as well as the mainstream British philosophy of education. Islamic education has three foundational aims of education: growth and self-development; civic engagement and contributing to the growth of society; and objectivity in seeking knowledge and thus finding God. On the other hand, the dominant British philosophy of education advocates two foundational aims - namely, preparation for the workforce, and asserting political influence.

The paper then discusses the strengths and weaknesses of the mainstream British model. Of these, the most significant were two: firstly, that it has no ontological foundation on which the philosophy is based; and secondly, that its implementation has proved to be selfdefeating, in that the model has caused the job market to be satiated, leaving workers 'overeducated' and not being able to fulfil their potential in the workforce. Thereafter, the paper discussed the Islamic educational model, which not only proved to be coherent and more conducive to the aims of current philosophers of education in Britain, but it also offers solutions to the weaknesses of the dominant British model.

The paper then proposes to synthesise the aims of both models without jeopardising the economy. It suggests implementing the Islamic model wholly. This includes adopting a pluralistic model, which will accommodate for differing philosophies to coexist in different institutes of learning across the country.

The answer to the question, therefore, is that the aims of education ought to help the learners grow, both as individuals and as citizens of a wider community; to raise and maintain the prestige of knowledge, learners and educators; and to maintain high standards of objectivity and academic integrity. The place of education and academia in society is for the tarbiyah (growth) of humankind in all aspects, which is different from the role of professional development and job-training; however, they are not mutually exclusive. That said, the next

28 'Abd al-Raḥmān Ibn Khaldūn, Muqaddimat Ibn Khaldūn (Damascus: Resalah Publishers, 2015). 
question that poses itself is this: while the Islamic model of education worked in Muslim civilisations over the spread of a millennium, to what extent will it work in a country under non-Muslim rule, like Britain? This can only be ascertained through an empirical experiment, which is beyond the scope of this paper.

\section{REFERENCES}

al-'Awnī, Hātim. Ikehtilāf al-Muftìn wa '-Mawqif al-Mațū̄b tijāhabū min 'Umūm al-Muslimin: Mu'așșalan min Adillat al-Wahyayn. Riyadh: Dār al-Șamīì̄, 2008.

al-Dihlawī, Shāh Waliyyullāh. 'Iqd al-Jìd fì Ahkeām al-Ijtihād wa '-Taqlìd. Edited by 'Abd al-Nașīr Aḥmad al-Malībārī. Kuwait: Dār al-Dịā̄', 2014.

al-Ghazālī, Abū Ḥāmid. Ihyyā’ 'Ulūm al-Dìn. 10 vols. Jeddah: Dār al-Minhāj, 2011.

al-Khallāl, Abū Bakr. Al-Hathth 'alā 'l-Tijärah wa 'Sināa'ah wa 'l- 'Amal wa '-Inkērr 'alā man Yadda'i 'l-Tawakkul fi Tark al-'Amal wa 'l-Hujjah 'alayhim fì Dhälik. Aleppo: Maktab al-Mațū̄àt al-Islāmiyyah, 1995.

al-Naysābūrī, Muslim. Saḥih Muslim. Edited by Muwaffaq Mar'ī. 6 vols. Damascus: Dār alFayḥ̄à, 2010.

al-Qaraḍāwī, Yusūf. Fiqh al-Zakāh: Dirāsah Muqāranah li Ahkāmihā wa Falsafatihà fì Daw' alQur'àn wa 'l-Sunnah. Damascus: Resalah Publishers, 2014.

al-Qazwīnī, Ibn Mājah Al-Sunan. 2. Edited by Shu 'ayb al-Arna'ūt et al. 5 vols. Damascus: AlRisālah al-' 'Alamiyyah, 2010.

al-Shātịīi, Abū Ishāā. Al-I'tiṣām. Edited by Salīm ibn 'Īd al-Hilālī. 2 vols. Riyadh: Dār Ibn alQayyim, 2010.

al-Sijistānī, Abū Dāwūd. Sunan Abì Dāwūid. Edited by Shu'ayb al-Arna'ùt et al. 7 vols. Damascus: Al-Risālah al- 'Ālamiyyah, 2012.

al-Tirmidhī, Muḥammad. Al-Jämi' al-Kabìr. 2. Edited by Shu'ayb al-Arna'ūt et al. 6 vols. Damascus: Al-Risālah al- 'Ālamiyyah, 2010.

Battu, H, and P J Sloane. "To what extent are ethnic minorities in Britain over-educated?" International Journal of Manpower 23, no. 3 (2002): 192-208. https://doi.org/10.1108/01437720210432194

Borus, György. “A New Account of Britain’s Economic Development.” Hungarian Journal of English and American Studies 23, no. 1 (2017): 229-241.

Brown, Jonathan. Misquoting Muhammad: The Challenge and Choices of Interpreting the Prophet's Legacy. London: Oneworld Publications, 2015.

Burgess, Tony. "Education in Britain, 1944 to the present: a response to Ken Jones's book of that title." Changing English 11, no. 1 (2004): 31-38. 
Cook, Bradley J. "Islamic Versus Western Conceptions of Education: Reflections on Egypt." International Review of Education 45, no. 3 (1999): 339-358. https://doi.org/10.1023/A:1003808525407

El Diwany, Tarek, ed. Islamic Banking and Finance: What it is and What it Could Be. Bolton: 1st Ethical Charitable Trust, 2010.

Friere, Paolo. Pedagogy of the Oppressed. 4. Translated by Myra Bergman Ramos. New York: The Continuum International Publishing Group Inc, 2005.

Günther, Sebastian. "Be Masters in That You Teach and Continue to Learn: Medieval Muslim Thinkers on Educational Theory." Comparative Education Review 50, no. 3 (2006): 367 388. https://doi.org/10.1086/503881

Ibn Khaldūn, 'Abd al-Raḥmān. 2015. Muqaddimat Ibn Khaldūn. Edited by Muṣtafā Shaykh Muṣtafā. Damascus: Resalah Publishers, 2015.

King, Jeanette. "The Worldview of Second Language Speakers of Māori." In Indigenous Language Revitalization: Encouragement, Guidance \& Lessons Learned, edited by Jon Reyhner and Louise Lockard, 97-108. Arizona: Northern Arizona University, 2009.

Linville, Mark D. “The Moral Argument.” In The Blackwell Companion to Natural Theology, edited by William Lane Craig and J P Moreland, 391-448. West Sussex: Blackwell Publishing Ltd, 2012.

Masud, Muhammad Khalid. "Islamic Modernism." In Islam and Modernity: Key Issues and Debates, edited by Muhammad Khalid Masud, Armando Salvatore and Martin van Bruinessen, 237-260. Edinburgh: Edinburgh University Press, 2012.

Moore, Alex. Teaching and Learning: Pedagogy, Curriculum and Culture. 2. Abingdon: Routledge, 2012.

Pring, Richard. Thinking Philosophically about Education: The Selected Works of Richard Pring. Abingdon: Routledge, 2019.

Ramadan, Tariq. In the Footsteps of the Prophet: Lessons from the life of Mubammad. New York: Oxford University Press, 2007.

Sahin, Abdullah. New Directions in Islamic Education: Pedagogy \& Identity Formation. Markfield: Kube Publishing Ltd, 2013.

Sheikh, Sajid Ullah, and Muhammad Abid Ali. 2019. "Al-Ghazali's Aims and Objectives of Islamic Education." Journal of Education and Educational Development 6 (11): 111-125. https:/ / eric.ed.gov/?id=EJ1216762

Winch, Christopher. "The Economic Aims of Education." Journal of Philosopby of Education 36, 1 (2002): 101-117. https://doi.org/10.1111/1467-9752.00262

Wyness, Michael. Childhood and Society. 2. London: Palgrave Macmillan, 2012.

Zaman, Muhammad Qasim. The Ulama in Contemporary Islam: Custodians of Change. Princeton: Princeton University Press, 2002. 